\title{
The Relationship Between Physical Activity Level and Obesity-related Chronic Disease: a Cohort Study
}

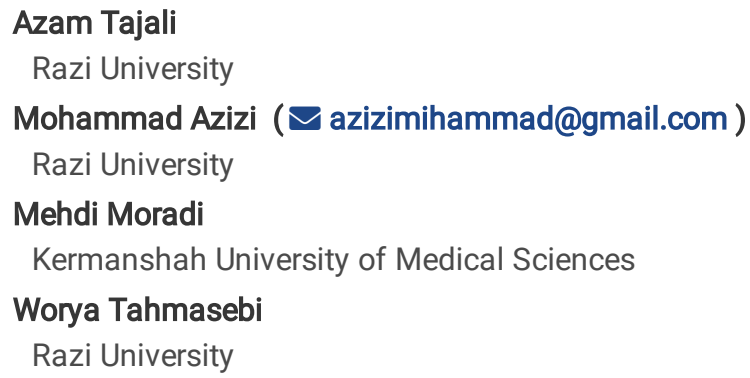

Research Article

Keywords: Physical activity, Obesity, Blood pressure, Diabetes, Non-communicable disease, Iranian psychiatrist

Posted Date: March 3rd, 2022

DOI: https://doi.org/10.21203/rs.3.rs-1381349/v1

License: (c) (i) This work is licensed under a Creative Commons Attribution 4.0 International License. Read Full License 


\section{Abstract}

Purpose: This study aimed to compare the physical activity level of men with women and to evaluate the relationship between physical activity level with obesity, diabetes, and hypertension in Ravansar, Kermanshah province, Iran.

Method: This study was conducted based on the data from Ravansar non-communicable disease (RaNCD) cohort study examining 10059 men and women aged 35-65. The body mass index, blood pressure, and fasting blood sugar were measured. The standard physical activity questionnaire (SPAQ) was obtained and the participants were divided into three categories; inactive, relatively active, and active using MET.

Results: The results show that $47.42 \%$ of participants in the cohort were male $(n=770)$. While the prevalence of diabetes was higher in men ( $7.98 \%$ of women vs. $8.39 \%$ of men), the prevalence of obesity ( $36.5 \%$ vs. $16.8 \%)$, and blood pressure $(18.28 \%$ vs. $16.8 \%$ ) were higher in women, respectively. Only $33.6 \%$ of men and $10.1 \%$ of women were categorized as active $(M E T \geq 45)(p<0.05)$. The results also indicate an inverse, significant relationship between the physical activity level and obesity, diabetes, and hypertension in both men and women, not in men $(P>0.001)$. Active men and women $(M E T s \geq 45)$ had lower risks for developing obesity, diabetes, and hypertension compared with inactive counterparts (METs $=24-36.5)$.

Conclusion: Due to the high prevalence of obesity and overweight and also the effect of increased physical activity on reducing the risk of obesity, diabetes, and hypertension development, suitable programs to increase the physical activity level must be considered in men and women.

\section{Introduction}

The increment of lifestyle-related diseases in recent decades had altered the epidemiology of diseases (1). The World Health Organization (WHO) has estimated the total number of deaths from non-communicable disease (NCD) disease to reach 52 million by 2030 (2). On the other hand, the development of urbanization, rapid lifestyle changes, unhealthy dietary habits (increased fats and simple sugars consumption), increased blood pressure due to psychological stress, and reduced physical activity levels are known to be the main risk factors of NCD (e.g, obesity, diabetes, and hypertension $(3,4)$.

Recent epidemiological studies have shown that the prevalence of overweight and obesity in Iran is higher than in Europe and the United States (5). Numerous studies have studied the relationship between physical activity level and cardiovascular disease, diabetes, and obesity that have shown physical activity as the main factors in the prevention of NCD in small samples(6). However, most of the previous studies mainly focused on the relationship between physical activity level and nutrition; while, rarely analyzed the relationship with NCD, and in some studies, the evaluation of physical activity level is limited to specific training hours or the leisure-time physical activity(7). Besides, it is not yet clear whether a high physical activity level has a greater protective effect than a moderate physical activity level (2).

According to the findings of the Third National Survey of Non-Communicable Disease Risk Factors (SuRFNCD-2007), 40\% of Iranian adults (31.6\% of men and $48.6 \%$ of women), especially women and elderly, are inactive (8). Another study also confirmed the low physical activity level in Iranian participants. The main factors of reduced physical activity level might involve female gender, living in the urban area, low socioeconomic status, obesity, diabetes, and old age(9). The reduction of the cardiovascular risk factors via increased physical activity level, and promoted lifestyle attitude support the idea that non-pharmacological approaches can prevent or control NCD.

Therefore, this study aimed to compare the physical activity level of men with women and to evaluate the relationship between physical activity level with obesity, diabetes, and hypertension in Ravansar, Kermanshah province, Iran.

\section{Materials And Methods}

\section{Study Design and Participants}

The data of the current study was obtained from the Ravansar non-communicable disease (RaNCD) cohort study, a part of the PERSIAN Cohort Studies (PCS), which has been performed since 2014 in Iranian adults. The details about the study design have already been published $(10,11)$. Inclusion criteria included; systolic and diastolic blood pressure (SBP/DBP) $\geq 140 / 90$ or a history of using antihypertensive drugs (12), fasting blood sugar (FBS) $\geq 126 \mathrm{mg} / \mathrm{dL}$ or a history of using insulin or oral hypoglycemic drugs, body mass index $(\mathrm{BMI}) \geq 30 \mathrm{~kg} / \mathrm{m} 2$ (13). Exclusion criteria included; the presence of any movement disabilities or any other chronic disease-causing inactivity.

\section{Measurements and Tools}


First, the purpose and the importance of the study were explained to the participants. Then, the demographic characteristics (e.g., age, sex, education, and medical information), medical history (e.g., hypertension, diabetes, and cardiovascular disease), and the dietary intake of the participants were obtained using related questionnaires and after confirming the accuracy of the information by the supervisor of the center, the data was finally registered. In case of problems, a re-follow-up was performed and if necessary, the participants were asked to complete the questionnaire correctly in the center (12).

The height and weight of the subjects were measured with an accuracy of $0.1 \mathrm{~cm}$ and $0.5 \mathrm{~kg}$, respectively. The BMI was calculated using weight $(\mathrm{kg})$ and height (m2) (14). Following the recommendation of the British Blood Pressure Association, the blood pressure was measured using blood pressure monitoring after 15 minutes of rest with two different measurements; Then, the mean of the measurements was considered as the mean SBP and DBP(15). Also, to measure the FBS, $7 \mathrm{ml}$ of blood was taken from the right anticoagulant vein after $8-$ 12 hours of fasting, and after centrifugation for $10-15$ minutes at $4^{\circ} \mathrm{C}$, serum samples were stored at $80^{\circ} \mathrm{C}$. The blood samples were then analyzed using the PARS Azmoon kit.

Also, the standard physical activity questionnaire (SPAQ) was used to assess the physical activity level. The SPAQ consisted of 22 questions for assessing the amount of daily physical activity level. Then, the data of the questionnaire were extracted and used based on the metabolic equivalent per hour per day (MET/h/day) (source). The participants were categorised in to three classes; inactive (24-35/9 MET/hour/day) relatively active (36-44/9 MET/hour/day) and active (MET/hour/day > 45) (16).

\section{Statistical Method}

The independent t-test was used to compare male and female, one-way analysis of variance ANOVA to compare between groups, and Pearson correlation coefficient to examine the relationship between variables. The logistic regression was used to predict the probability of obesity, overweight, diabetes, and hypertension that were presented as adjusted odds ratio (OR) and 95\% confidence interval (CI) based on the physical activity level. All statistical tests were performed using SPSS 22 with a significance level of 0.05 .

\section{Results}

The results show that $47.42 \%(n=4770$ out of 10059) of participants in the RaNCD were male and $52.58 \%(n=5289)$ were female. The

prevalence of obesity, diabetes and hypertension were higher in women (46.67\%, 8.39\%, and $18.28 \%)$ than men (36.55\%, $7.98 \%$, and $12.83 \%)$. While the prevalence of overweight in men was higher than in women (46.67\% vs. 40.37\%) (Table 1). As Fig. 1 shows, BMI and DBP in women were significantly higher than men $(p<0.001)$. 
Table 1

Demographic characteristics of the participants

\begin{tabular}{|c|c|c|c|c|c|c|c|c|c|c|c|}
\hline \multirow[t]{2}{*}{ Variable } & & \multicolumn{5}{|l|}{ Male } & \multicolumn{5}{|c|}{ Female } \\
\hline & & $(\%) \mathrm{N}$ & Inactive & $\begin{array}{l}\text { Rarely } \\
\text { Active }\end{array}$ & Active & $\begin{array}{l}P \\
\text { value }\end{array}$ & $(\%)$ & Inactive & $\begin{array}{l}\text { Rarely } \\
\text { Active }\end{array}$ & Active & $\begin{array}{l}P \\
\text { value }\end{array}$ \\
\hline \multirow{2}{*}{\multicolumn{2}{|c|}{ Total }} & & 1589 & 1594 & 1584 & \multirow{2}{*}{$\begin{array}{l}< \\
0.001\end{array}$} & & 528 & 3571 & 1188 & \multirow{2}{*}{$\begin{array}{l}< \\
0.001\end{array}$} \\
\hline & & & (\%33.33) & (\%33.44) & (\%33.23) & & & (\%9.99) & (\%67.54) & (\%22.47) & \\
\hline \multirow[t]{3}{*}{$\mathrm{Age}^{\mathrm{a}}$} & $35-44$ & 40.04 & 626 & 627 & 656 & \multirow[t]{3}{*}{0.242} & 39.52 & 441 & 1477 & 171 & \multirow{3}{*}{$\begin{array}{l}< \\
0.001\end{array}$} \\
\hline & $45-54$ & 35.95 & 561 & 569 & 584 & & 33.45 & 330 & 1226 & 212 & \\
\hline & $55-65$ & 24 & 397 & 398 & 349 & & 27.04 & 417 & 868 & 145 & \\
\hline \multirow[t]{2}{*}{ Marital $^{a}$} & Married & 97.15 & 1531 & 1553 & 1547 & \multirow[t]{2}{*}{0.351} & 83.89 & 896 & 3079 & 461 & \multirow{2}{*}{$\begin{array}{l}< \\
0.001\end{array}$} \\
\hline & Single & 2.58 & 53 & 41 & 42 & & 16.11 & 292 & 492 & 67 & \\
\hline \multirow{5}{*}{$\begin{array}{l}\text { Education } \\
\text { (Years) }\end{array}$} & Illiterate & 12.96 & 131 & 201 & 286 & \multirow{5}{*}{$\begin{array}{l}< \\
0.001\end{array}$} & 35.39 & 435 & 1171 & 265 & \multirow{5}{*}{$\begin{array}{l}< \\
0.001\end{array}$} \\
\hline & $1-5$ & 28.87 & 334 & 456 & 585 & & 46.61 & 495 & 1738 & 232 & \\
\hline & $6-9$ & 24.23 & 351 & 404 & 401 & & 9.81 & 137 & 358 & 24 & \\
\hline & $10-12$ & 20.63 & 374 & 343 & 266 & & 5.37 & 84 & 195 & 5 & \\
\hline & $>13$ & 13.31 & 394 & 190 & 51 & & 2.82 & 37 & 109 & 2 & \\
\hline \multirow[t]{3}{*}{ Smoking $^{a}$} & No & 63.61 & 1022 & 1003 & 1000 & \multirow[t]{3}{*}{0.382} & 94.77 & 1107 & 3396 & 494 & \multirow[t]{3}{*}{0.072} \\
\hline & Current & 22.54 & 348 & 349 & 373 & & 2.03 & 26 & 70 & 11 & \\
\hline & Former & 13.58 & 208 & 240 & 211 & & 3.2 & 50 & 97 & 22 & \\
\hline \multirow{2}{*}{$\begin{array}{l}\text { Alcohol } \\
\text { Consumption }\end{array}$} & No & 93.5 & 1540 & 1403 & 1487 & \multirow[t]{2}{*}{0.456} & 93.9 & 1256 & 3175 & 497 & \multirow[t]{2}{*}{0.782} \\
\hline & Yes & 6.5 & 106 & 100 & 105 & & 6.1 & 88 & 201 & 31 & \\
\hline \multirow{3}{*}{$\begin{array}{l}\text { BMI } \\
\left(\mathrm{kg} / \mathrm{m}^{2}\right)\end{array}$} & Normal & 36.46 & 473 & 759 & 332 & \multirow{3}{*}{$\begin{array}{l}< \\
0.001\end{array}$} & 22.72 & 236 & 473 & 466 & \multirow{3}{*}{$\begin{array}{l}< \\
0.001\end{array}$} \\
\hline & OW & 46.67 & 548 & 767 & 261 & & 40.37 & 786 & 1463 & 1304 & \\
\hline & Obesity & 16.87 & 699 & 677 & 204 & & 36.55 & 171 & 204 & 151 & \\
\hline \multirow[t]{2}{*}{ Diabetes } & No & 92.02 & 1408 & 1459 & 1489 & \multirow{2}{*}{$\begin{array}{l}< \\
0.001\end{array}$} & 91.61 & 1069 & 3253 & 494 & \multirow[t]{2}{*}{0.091} \\
\hline & Yes & 7.98 & 161 & 125 & 92 & & 8.39 & 109 & 300 & 32 & \\
\hline Hypertension $^{a}$ & No & 87.17 & 1346 & 1390 & 1411 & 0.005 & 81.72 & 915 & 2949 & 444 & $<$ \\
\hline & Yes & 12.83 & 235 & 202 & 174 & & 18.28 & 268 & 616 & 80 & \\
\hline $\mathrm{Hei}^{\mathrm{a}}$ & $\begin{array}{l}1=\text { Very } \\
\text { very Poor } \\
=1\end{array}$ & 21.80 & 288 & 334 & 415 & $\begin{array}{l}< \\
0.001\end{array}$ & 20.33 & 229 & 686 & 156 & $\begin{array}{l}< \\
0.001\end{array}$ \\
\hline & Poor $=2$ & 20.19 & 285 & 315 & 360 & & 18.37 & 209 & 632 & 128 & \\
\hline & $\begin{array}{l}\text { Moderate } \\
=3\end{array}$ & 22.20 & 376 & 347 & 333 & & 20.76 & 260 & 736 & 98 & \\
\hline & Rich = 4 & 18.67 & 308 & 319 & 257 & & 19.11 & 229 & 693 & 86 & \\
\hline & $\begin{array}{l}\text { High } \\
\text { Rich = } 5\end{array}$ & 17.18 & 324 & 273 & 220 & & 21.43 & 257 & 818 & 55 & \\
\hline Physical Activit & & MET & $\begin{array}{l}33 \pm \\
2.07\end{array}$ & $\begin{array}{l}40 \pm \\
2.42\end{array}$ & $\begin{array}{l}55.3 \pm \\
8.2\end{array}$ & $\begin{array}{l}< \\
0.001\end{array}$ & & $\begin{array}{l}34.3 \pm \\
1.7\end{array}$ & $\begin{array}{l}39.5 \pm \\
2.1\end{array}$ & $\begin{array}{l}49.1 \pm \\
3.7\end{array}$ & $\begin{array}{l}<.001 \\
0.001\end{array}$ \\
\hline & & kj & $\begin{array}{l}174.8 \pm \\
11\end{array}$ & $\begin{array}{l}150.5 \pm \\
3.1\end{array}$ & $\begin{array}{l}192.4 \pm \\
41\end{array}$ & & & $\begin{array}{l}151.8 \pm \\
7.6\end{array}$ & $\begin{array}{l}218 \pm \\
66.7\end{array}$ & $\begin{array}{l}188 \\
\pm .34\end{array}$ & \\
\hline
\end{tabular}


There were significant differences in BMI among active, insufficiently active, and inactive both men $(F(2,4692)=47.45, p<.00)$ and woman $(F(2,5213)=21.90, p<.001)$. There were also significant differences in FBS between active and inactive men $(F(2,4705)=3.33, p=.036)$ and woman $(F(2,5215)=3.41, p=.033)$. In addition, differences were detected among active, insufficiently active, and inactive women in $\operatorname{SBP}(F(2,5242)=4.45, \mathrm{p}=.021)$. The DBP among active men was significantly different from insufficiently active and inactive men $(F(2$, $5221)=6.17, p=.002)$; however, no significant difference was, observed in SBP in men (Fig. 1).

The results of the Pearson correlation test showed significant negative relationships between the physical activity levels and obesity in women $(r=-.093, p<.001$, and men, $r=-.126, p<.001)$ (Fig. 2). There were also negative correlations between the physical activity level and FBS both in women $(r=-.040, p=.004)$ and men $(r=-.043, p=.003)$. In contrast, significant positive relationships were noticed between obesity and diabetes in men $(r=.105, p<.001)$ and women $(r=.082, p<.001)$. Moreover, physical activity level of women was inversely correlated with blood pressure $(r=-.055, p<.001)$; however, no such a significant correlation was detected in men.

Regarding the results of the logistic regression analysis, after adjusting the confounding variables, decreased odds ratio of obesity, diabetes, and hypertension was found with increasing physical activity level. The odds ratio of obesity was significant in both men and women while that of diabetes, and hypertension were only significant in men, and women, respectively. In general, the odds ratio of obesity, diabetes, and hypertension were significantly lower in insufficiently active (MET = 36.6-44.9) and active participants (MET $\geq 45)$ compared with their inactive counterparts (MET = 24-36.5). After controlling other variables (Model 3), it was shown that only active physical activity levels significantly affected obesity, diabetes, and hypertension, respectively, $(\mathrm{OR}(95 \% \mathrm{Cl})=0.77(0.64,0.93), 0 \mathrm{O}(95 \% \mathrm{Cl})=0.74(0.58,0.94)$, and OR $(95 \% \mathrm{Cl})=0.49(0.43,0,56))($ see Table 2$)$. 
Table 2

Univariate analyses of factors affecting the prevalence of obesity, diabetes, and hypertension in RaNCD

\begin{tabular}{|c|c|c|c|c|c|}
\hline \multirow[t]{2}{*}{ Variables } & & & & **model 2 & ***model 3 \\
\hline & & OR $(95 \% \mathrm{Cl})$ & OR $(95 \% \mathrm{Cl})$ & OR $(95 \% \mathrm{Cl})$ & OR $(95 \% \mathrm{Cl})$ \\
\hline \multicolumn{6}{|l|}{ Total } \\
\hline \multirow{2}{*}{$\begin{array}{l}\text { BMI }\left(\mathrm{Kg} / \mathrm{m}^{2}\right) \\
\text { (Ref:24-36.5) }\end{array}$} & Insufficiently active & $0.99(0.89,1.1)$ & $0.92(0.82,1.03)$ & $0.91(0.81,1.01)$ & $0.92(0.82,1.02)$ \\
\hline & active & $0.49(0.43,0.56)$ & $0.49(0.43,0.56)$ & $0.48(0.42,0.55)$ & $0.49(0.43,0.56)$ \\
\hline \multirow{2}{*}{$\begin{array}{l}\text { Diabetes (mg/dl) } \\
\text { (Ref:24-36.5) }\end{array}$} & Insufficiently active & $0.82(0.7,0.97)$ & $0.91(0.77,1.08)$ & $0.91(0.76,1.07)$ & $0.94(0.79,1.12)$ \\
\hline & active & $0.57(0.46,0.71)$ & $0.64(0.51,0.81)$ & $0.65(0.51,0.83)$ & $0.74(0.58,0.94)$ \\
\hline \multirow{2}{*}{$\begin{array}{l}\text { Hypertension }(\mathrm{mmHg}) \\
\text { (Ref:24-36.5) }\end{array}$} & Insufficiently active & $0.84(0.74,0.95)$ & $0.88(0.77,1.01)$ & $0.87(0.75,0.99)$ & $0.89(0.77,1.02)$ \\
\hline & active & $0.61(0.52,0.72)$ & $0.62(0.52,0.74)$ & $0.67(0.56,0.80)$ & $0.77(0.64,0.93)$ \\
\hline \multicolumn{6}{|l|}{ Men } \\
\hline \multirow{2}{*}{$\begin{array}{l}\text { BMI }\left(\mathrm{Kg} / \mathrm{m}^{2}\right) \\
(\text { Ref:24-36.5) }\end{array}$} & Insufficiently active & $0.81(0.7,0.94)$ & $0.84(0.72,0.98)$ & $0.8(0.69,0.94)$ & $0.83(0.71,0.97)$ \\
\hline & active & $0.54(0.47,0.63)$ & $0.57(0.48,0.66)$ & $0.54(0.46,0.63)$ & $0.55(0.47,0.65)$ \\
\hline \multirow{2}{*}{$\begin{array}{l}\text { Diabetes }(\mathrm{mg} / \mathrm{dl}) \\
\text { (Ref:24-36.5) }\end{array}$} & Insufficiently active & $0.74(0.58,0.95)$ & $0.79(0.61,1.02)$ & $0.78(0.6,1.01)$ & $0.82(0.63,1.07)$ \\
\hline & active & $0.54(0.41,0.7)$ & $0.61(0.46,0.82)$ & $0.6(0.44,0.8)$ & $0.67(0.49,0.9)$ \\
\hline \multirow{2}{*}{$\begin{array}{l}\text { Hypertension (mmHg) } \\
\text { (Ref:24-36.5) }\end{array}$} & Insufficiently active & $0.83(0.67,1.01)$ & 0/83(0/66,1/03) & $0 / 82(0.65,1.02)$ & $0.87(0.69,1.09)$ \\
\hline & active & $0.7(0.57,0.87)$ & $0.73(0.58,0.93)$ & $0 / 75(0.59,0.95)$ & $0.88(0.69,1.12)$ \\
\hline \multicolumn{6}{|l|}{ Women } \\
\hline \multirow{2}{*}{$\begin{array}{l}\text { BMI }\left(\mathrm{Kg} / \mathrm{m}^{2}\right) \\
\text { (Ref:24-36.5) }\end{array}$} & Insufficiently active & $0.88(0.75,1.04)$ & $0.82(0.69,0.97)$ & $0.81(0.66,0.96)$ & $0.8(0.96,0.76)$ \\
\hline & active & $0.52(0.41,0.65)$ & $0.59(0.46,0.76)$ & $0.57(0.45,0.74)$ & $0.59(0.46,0.76)$ \\
\hline \multirow{2}{*}{$\begin{array}{l}\text { Diabetes (mg/dl) } \\
\text { (Ref:24-36.5) }\end{array}$} & Insufficiently active & $0.9(0.71,1.13)$ & $1.03(0.81,1.3)$ & $1.04(0.82,1.3)$ & $1.1(0.86,1.4)$ \\
\hline & active & $0.63(0.42,0.95)$ & $0.74(0.48,1.14)$ & $0.79(0.51,1.2)$ & $0.89(0.58,1.3)$ \\
\hline \multirow{2}{*}{$\begin{array}{l}\text { Hypertension (mmHg) } \\
\text { (Ref:24-36.5) }\end{array}$} & Insufficiently active & $0.71(0.6,0.83)$ & $0.83(0.7,1)$ & $0.84(0.7,1)$ & $0.84(0.7,1.01)$ \\
\hline & active & $0.61(0.46,0.8)$ & $0.59(0.44,0.8)$ & $0.63(0.46,0.85)$ & $0.67(0.49,0.91)$ \\
\hline \multicolumn{6}{|c|}{ *Model 1 adjusted for all age, marital, education, place, smoking, and alcohol. } \\
\hline \multicolumn{6}{|c|}{ ** Model 2 adjusted for Energy intake, and Energy Consumption in addition to the variables in model 1} \\
\hline \multicolumn{6}{|c|}{$\star \star \star$ Model 3 adjusted for other variables to the variables in model 1 and 2} \\
\hline
\end{tabular}

\section{Discussion}

This study aimed to investigate the level of physical activity and its relationship with the prevalence of non-communicable disease (NCD) in Ravansar, Iran. The results of the present study showed that the prevalence of obesity, diabetes, and blood pressure are related to the level of physical activity. Also, in our study, the difference between the prevalence of obesity, diabetes, and hypertension in men and women living in Ravansar, Iran was observed. Bergman et al. reported a 37.1\% inactive physical activity level in 1,470 Swedish men and women(17). Also, Hull et al. (2003) reported low physical activity levels in 3128 Brazilian individuals(18). The inactive physical activity level in UAE (39.5\%), Pakistan (13.5\%), and Tunisia (11.5\%) (4) was lower than this study. The results also indicated significant differences in physical activity levels between men and women; with women being more inactive due to being housewives. The data in this study provide evidence for the importance of physical activity levels in the prevalence of non-communicable diseases in both men and women.

In general, the prevalence of overweight and obesity in men and women was $43.5 \%$ and $27.2 \%$, respectively. The increased incidence of obesity is justifiable when noticing the negative relationship between obesity and physical activity levels in the present study. Yar Ahmadi et al. (2013) reported the prevalence of overweight and obesity to be $27 \%$ and $20 \%$, respectively(19), which were lower than this study. In the 
United States, the prevalence of obesity in adults over the age of 20 is reported to be approximately $38.3 \%$ in women and $34.3 \%$ in men (20), which is consistent with our findings regarding the significantly higher prevalence of obesity in women than men.

In general, there was no significant difference between the prevalence of hypertension in men and women (12.83\% and $18.28 \%$ ). Consistent with the results of the present study, Masoud Mirzaei et al. (2016) have shown an approximately equal incidence of hypertension in both men and women(21). The prevalence of hypertension in this cohort was lower than in South Korea (19.8\%), China (27\%), the United States (28\%) and the Middle East Arab countries (32.2\%), and the large prospective cohort of Cuban adults (34\%) (35,36). One of the most important reasons for the low prevalence of hypertension in Ravansar might be the low hypertension risk factors including; smoking (11.7\%), alcohol consumption $(6.3 \%)$, and diabetes $(6.6 \%)(22,23)$. Compared to the IDF report on the global prevalence of diabetes $(8.3 \%)(24)$, we found the prevalence of diabetes to be $7.98 \%$ in men and $8.39 \%$ in women.

Our findings showed a positive and significant relationship between high body mass index and diabetes in inactive individuals. Also, a positive relationship was observed between body weight gain and hypertension. Based on our findings, the presence of obesity, diabetes, and hypertension might be life-threatening due to the higher inactive population in this study. Thus, without effective and timely interventions the incidence of cardiovascular disease in individuals with high-risk lifestyles is inevitable (24).

Epidemiological studies have shown that physical activity is effective in the early prevention of diabetes, cardiovascular disease, and hypertension and can reduce body fat percentage and insulin resistance (24). The major strength of this study is that it is based on a large prospective cohort study with a high response rate and multiple measurements of self-rated health and chronic diseases over a long followup period. Also, lifestyle factors (such as obesity, diet, or smoking) that could confound the relationships shown were controlled in the analysis. Finally, in our study, the analyses were limited to ages between 35-65. Therefore, more studies in other age groups are needed to confine the relationship between physical activity levels and obesity-related chronic disease.

\section{Conclusion}

Overall, choosing a lifestyle with a low physical activity level was most remarkably associated with the incidence of chronic NCD, especially overweight and obesity. Therefore, to reduce the prevalence of obesity, diabetes, and hypertension in older adults, appropriate and effective strategies to promote public health awareness, seem necessary.

\section{Declarations}

\section{Ethical Approval and consent to participate}

The cohort study was given ethical approval by the Ethics Committee of Kermanshah University of Medical Sciences (ethics approval number: KUMS.REC.1394.318).

\section{Consent for publication}

Not applicable

\section{Availability of data and materials}

Data will be available upon request from the corresponding author.

\section{Competing interests}

The authors declare no conflicts of interest

\section{Fundings}

This study was supported by the Ministry of Health and Medical Education of Iran and Kermanshah University of Medical Science (Grant No: 92472).

\section{Authors' contributions}

AT and MA contributed in conception and design of the research; AT, MMN, and WT contributed to data collection; MA and WT contributed to the acquisition and analysis of the data; MA and WT contributed to the interpretation of the data; MMN, MA, and WT contributed to draft the manuscript. All authors are in agreement with the manuscript and declare that the content has not been published elsewhere. 
The RaNCD is part of the PERSIAN national cohort and we would like to thank Professor Reza Malekzadeh Deputy of Research and Technology at the Ministry of Health and Medical Education of Iran and Director of the PERSIAN cohort and also Dr. Hossein Poustchi Executive Director of the PERSIAN cohort for all their supports during design and running of RaNCD.

\section{References}

1. Murray CJ, Lopez AD. Global mortality, disability, and the contribution of risk factors: Global Burden of Disease Study. The lancet. 1997;349(9063):1436-42.

2. Mok A, Khaw K-T, Luben R, Wareham N, Brage S. Physical activity trajectories and mortality: population based cohort study. Bmj. 2019;365.

3. Mendis S, Davis S, Norrving B. Organizational update: the world health organization global status report on noncommunicable diseases 2014; one more landmark step in the combat against stroke and vascular disease. Stroke. 2015;46(5):e121-e2.

4. Esteghamati A, Khalilzadeh O, Rashidi A, Kamgar M, Meysamie A, Abbasi M. Physical activity in Iran: results of the third national surveillance of risk factors of non-communicable diseases (SuRFNCD-2007). Journal of Physical Activity and Health. 2011;8(1):27-35.

5. Walia S, Liepert B. Perceived facilitators and barriers to physical activity for rural youth: an exploratory study using photovoice. Rural and Remote Health. 2012;12(1842).

6. Sobngwi E, Mbanya JN, Unwin N, Kengne A, Fezeu L, Minkoulou E, et al. Physical activity and its relationship with obesity, hypertension and diabetes in urban and rural Cameroon. International journal of obesity. 2002;26(7):1009-16.

7. Sahebkar M, Heidarian Miri H, Noormohammadpour P, Akrami R, Mansournia N, Tavana B, et al. Prevalence and correlates of low physical activity in the Iranian population: national survey on non-communicable diseases in 2011. Scandinavian journal of medicine \& science in sports. 2018;28(8):1916-24.

8. Ghassemi H, Harrison G, Mohammad K. An accelerated nutrition transition in Iran. Public health nutrition. 2002;5(1a):149-55.

9. Behroozi-Fard-Mogaddam A, Ebrahimi-Mameghani M, Asghari-Jafarabadi M. Snack pattern in relation to body mass index and lipid profile in overweight and obese adults in Tabriz. Medical Journal of Tabriz University of Medical Sciences and Health Services. 2017;39(4):20-8.

10. Momenan AA, Delshad M, Mirmiran P, Ghanbarian A, Azizi F. Leisure time physical activity and its determinants among adults in Tehran: Tehran Lipid and Glucose Study. International journal of preventive medicine. 2011;2(4):243.

11. Eghtesad S, Mohammadi Z, Shayanrad A, Faramarzi E, Joukar F, Hamzeh B, et al. The PERSIAN cohort: providing the evidence needed for healthcare reform. Archives of Iranian medicine. 2017;20(11):691-5.

12. Ainsworth BE, Jacobs Jr DR, Leon AS, Richardson MT, Montoye HJ. Assessment of the accuracy of physical activity questionnaire occupational data. Journal of occupational medicine: official publication of the Industrial Medical Association. 1993;35(10):1017-27.

13. Ghaffarpour M, Houshiar-Rad A, Kianfar H. The manual for household measures, cooking yields factors and edible portion of foods. Tehran: Nashre Olume Keshavarzy. 1999;7(213):42-58.

14. Mbanya J, Ngogang J, Salah J, Minkoulou E, Balkau B. Prevalence of NIDDM and impaired glucose tolerance in a rural and an urban population in Cameroon. Diabetologia. 1997;40(7):824-9.

15. Beevers G, Lip GY, O'Brien E. Blood pressure measurement: Part II-Conventional sphygmomanometry: Technique of auscultatory blood pressure measurement. Bmj. 2001;322(7293):1043-7.

16. Schap T, Kuczynski K, Hiza H. Healthy eating index-Beyond the score. Journal of the Academy of Nutrition and Dietetics. 2017;117(4):519-21.

17. Bergman P, Grjibovski AM, Hagströmer M, Bauman A, Sjöström M. Adherence to physical activity recommendations and the influence of socio-demographic correlates-a population-based cross-sectional study. BMC Public Health. 2008;8(1):1-9.

18. Hallal PC, Victora CG, Wells JCK, Lima RC. Physical inactivity: prevalence and associated variables in Brazilian adults. Medicine \& Science in Sports \& Exercise. 2003;35(11):1894-900.

19. Yarahmadi S, Etemad K, Hazaveh AM, Azhang N. Urbanization and non-communicable risk factors in the capital city of 6 big provinces of Iran. Iranian journal of public health. 2013;42(Supple1):113.

20. Ogden CL, Carroll MD, Fryar CD, Flegal KM. Prevalence of obesity among adults and youth: United States, 2011-2014. 2015.

21. Mirzaei M, Moayedallaie S, Jabbari L, Mohammadi M. Prevalence of hypertension in Iran 1980-2012: a systematic review. The Journal of Tehran University Heart Center. 2016;11(4):159. 
22. Tanjani PT, Motlagh ME, Nazar MM, Najafi F. The health status of the elderly population of Iran in 2012. Archives of Gerontology and Geriatrics. 2015;60(2):281-7.

23. Tanjani PT, Moradinazar M, Mottlagh ME, Najafi F. The prevalence of diabetes mellitus (DM) type II among Iranian elderly population and its association with other age-related diseases, 2012. Archives of gerontology and geriatrics. 2015;60(3):373-9.

24. Hu G, Barengo NC, Tuomilehto J, Lakka TA, Nissinen A, Jousilahti P. Relationship of physical activity and body mass index to the risk of hypertension: a prospective study in Finland. Hypertension. 2004;43(1):25-30.

\section{Figures}
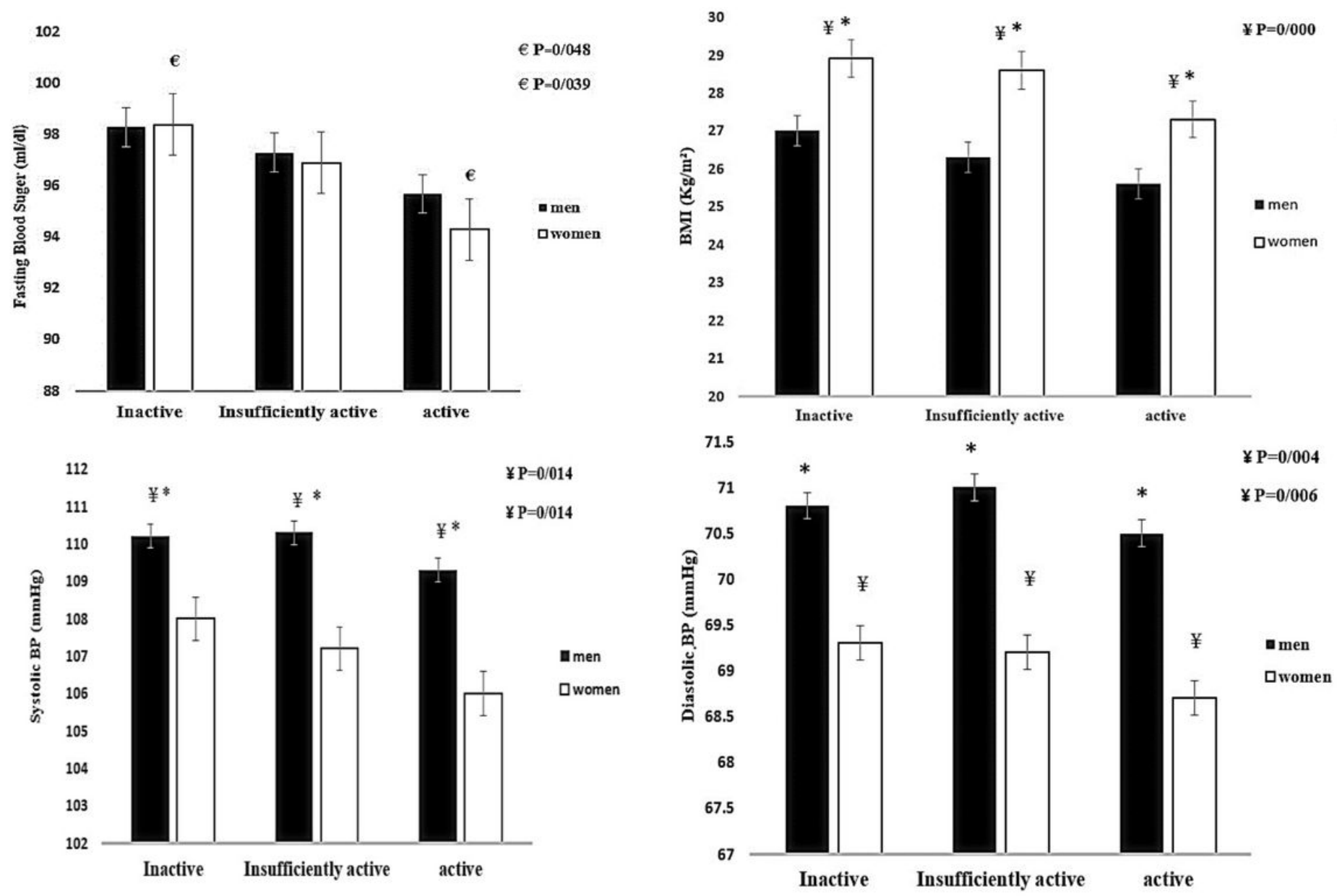

Figure 1

BMI, Fasting Blood Sugar, and Blood Pressure in different Physical Activity Levels in Men and Women 

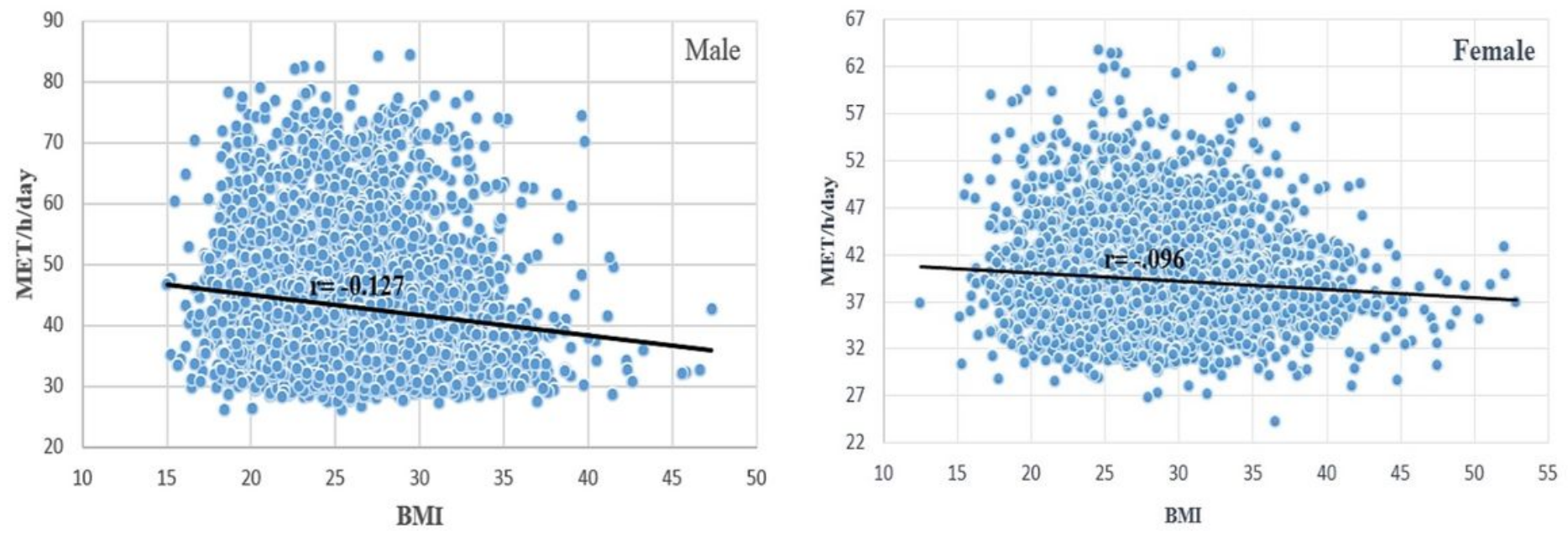

Figure 2

Correlations between BMI and Levels of Physical Activity in Men and Women 